\title{
Influence of temperature and nutrient content on lipid production in freshwater microalgae cultures
}

\author{
JULIANA E. BOHNENBERGER ${ }^{1,2}$ and LUCIANE O. CROSSETTI ${ }^{1,2}$ \\ ${ }^{1}$ Universidade do Vale do Rio dos Sinos, Av. Unisinos, 950, Cristo Rei, 93022-000 São Leopoldo, RS, Brasil \\ ${ }^{2}$ Universidade Federal do Rio Grande do Sul, Av. Bento Gonçalves, 9500, Agronomia, 91501-970 Porto Alegre, RS, Brasil \\ Manuscript received on April 11, 2013; accepted for publication on October 14, 2013
}

\begin{abstract}
The production of biomass by microalgae is considered a clean alternative compared to other plant crops that require large areas for cultivation and that generate environmental impacts. This study evaluated the influence of temperature and nutrients on lipid contents of cultured species of freshwater microalgae, with a view toward using these lipids for biodiesel production. Two strains of Monoraphidium contortum, a culture containing Chlorella vulgaris and Desmodesmus quadricauda and another strain of Microcystis aeruginosa were maintained in the laboratory for six days, in five culture media: modified ASM-1 (control, with high concentrations of phosphate and nitrate; phosphorus-deficient; non-limiting phosphate; nitrogendeficient; and non-limiting nitrate). The cultures were then exposed to temperatures of $13{ }^{\circ} \mathrm{C}, 25^{\circ} \mathrm{C}$ (control) and $37^{\circ} \mathrm{C}$ for eight days $(\mathrm{n}=3)$. Lipids were extracted by the cold-solvent (methanol and chloroform) method. On average, the highest total lipid yields were observed when the strains were maintained at $13^{\circ} \mathrm{C}$ and in the non-limiting nitrate medium. The lipid percentage varied depending on the concentration of algal biomass. This study showed that manipulation of controlling factors can increase the lipid concentration, optimizing the total production in order to use this raw material for biodiesel.
\end{abstract}

Key words: energy biomass, Monoraphidium, Chlorella, Desmodesmus, Microcystis, lipid accumulation.

\section{INTRODUCTION}

The extensive use of fossil fuels is considered unsustainable because of its finite nature and the accumulation of carbon dioxide in the atmosphere (Plá 2002, Borges et al. 2007, Walker 2009, Goldemberg 2009). From this, comes the need for effective options to replace these fuels with viable alternatives that are renewable, clean, inexpensive and sustainable. Several plant-based materials have been tested, including corn, soy, canola and palm oil, among others (Chisti 2007, Cheng et al. 2009).

Correspondence to: Juliana Elisa Bohnenberger

E-mail: bonhju@yahoo.com.br
However, these crops require large areas of planted land to provide significant amounts of biomass for fuel production, which reduces land availability for food crops.

In view of these difficulties, microalgae appear to be an excellent choice. These simple, unicellular, photosynthesizing organisms have been identified as a sustainable alternative in the search for raw materials to produce alternative fuel (Smith et al. 2010, Huang et al. 2010, Mata et al. 2010). They have short life cycles and can double their biomass in 24 hours when nutritional conditions are appropriate, and nitrogen $(\mathrm{N})$ and phosphorus 
(P) are among the most important resources needed to produce them (Haag 2007). This rapid growth allows aliquots of cultures to be removed daily for lipid extraction.

Studies in several parts of the world have revealed the main advantages and disadvantages of the use of algae as sources of energy (Brennan and Owende 2010). The rapid replication and high percentage of oil present in many species of algae, reaching about $80 \%$ of their biomass, are some of these advantages (Sporalore et al. 2006, Chisti 2007, Harwood and Guschina 2009). Also, unlike other plants, algae do not require large areas for cultivation, and can be up to 20 times more productive per unit area than the top oilseed crops (Chisti 2007). However, large-scale cultivation in the laboratory is also costly since it is necessary to control conditions of light, carbon dioxide and nutrients, and especially the amount of nitrogen present in the culture medium, because this element is responsible for forming lipids. This is one of the few disadvantages of using these organisms.

There is a need to identify the biochemical and environmental factors that could accelerate and promote the accumulation of oil (Chisti 2007). Algae differ in the amount of fatty acids biosynthesized, even among strains of the same species (Aquarone et al. 1983), and therefore proper culture conditions are very important for the synthesis of fats. It is possible to divert the biosynthetic metabolism to lipid synthesis through changes in culture conditions, thus obtaining fats as the main constituent instead of proteins (Aquarone et al. 1983). In other words, by manipulating the temperature and the chemical composition of the culture medium, it is possible to increase the production of lipids (Behrens and Kyle 1996, Mandal and Mallick 2009). One study showed that $\mathrm{N}$ deficiency increased the lipid content of a culture of Chlorella by $63 \%$ (Illman et al. 2000). P limitation also appears to stimulate lipid accumulation, as found by Rhee (1978); i.e., the lipid content was higher when $\mathrm{P}$ was unavailable. However, most studies have found that $\mathrm{N}$ deficiency produces a higher percentage of lipid than P deficiency (Illman et al. 2000, Mandal and Mallick 2009, Feng et al. 2012). With respect to temperature, one study determined that raising the temperature from $30^{\circ} \mathrm{C}$ to $42^{\circ} \mathrm{C}$ increased the lipid content of the bluegreen alga Spirulina maxima (Paoletti et al. 1980).

In view of the limited knowledge on the physiology of many species of algae that could potentially be used for energy production, a good choice is the cosmopolitan microalgae, such as species of Chlorophyceae, which are easy to grow and commonly found in plankton samples. Species of Chlorella have been considered promising candidates for commercial production of biodiesel, because the growth rate and lipid content of many strains can reach high levels. Furthermore, accumulated knowledge and experience indicate that members of this genus can be useful in biofuel production (Feng et al. 2012). In comparison, cyanobacteria have been studied for a relatively short period, although they have high potential for biomass production, as illustrated by their blooms, which create numerous problems in reservoirs, especially for drinking-water supply. However, there are still divergences with regard to the cause and consequence of particular factors in the development of cyanobacteria (Dantas et al. 2011).

This study followed the hypothesis that manipulations of temperature and $\mathrm{N}$ and $\mathrm{P}$ concentrations can help to optimize production. We evaluated the effects of manipulating temperature and nutrients on lipid content in the cultured freshwater microalgae species Monoraphidium contortum (Thuret) Komàrková-Legnerová, Chlorella vulgaris Beijerinck, Desmodesmus quadricauda (Turpin) Brébrisson and Microcystis aeruginosa Kützing, with a view to their future use in biodiesel production.

\section{MATERIALS AND METHODS}

Four strains were used in this study. Strains LECV-1 and LECV-2 were both Monoraphidium 
contortum, isolated from the cities of São Leopoldo and Porto Alegre, which are located $50 \mathrm{~km}$ distant from each other in southern Brazil. Culture LECV3, containing the species Chlorella vulgaris and Desmodesmus quadricauda, was isolated from an impoundment in the city of São Leopoldo, southern Brazil. Strain LEA-04, containing Microcystis aeruginosa, was provided by the Laboratory of Aquatic Ecology of the Federal University of Juiz de Fora, Minas Gerais, southeast Brazil. The cultures were maintained in 250-ml Erlenmeyer flasks containing $100 \mathrm{ml}$ of ASM-1 modified medium (Aguiar and Azevedo in CETESB 1992), under controlled conditions $\left(25^{\circ} \mathrm{C}\right)$, with a photoperiod of 12:12 $\mathrm{h}$ and light intensity of $2492 \mathrm{lux}$, provided by fluorescent lamps $(20 \mathrm{~W})$.

This study tested three temperatures: $25^{\circ} \mathrm{C}$ (the control temperature), $13^{\circ} \mathrm{C}$ and $37^{\circ} \mathrm{C}$. Five culture media modified from ASM-1 were also tested: C (control), with high concentrations of P $(0.8244 \mathrm{~g}$ $\mathrm{L}^{-1}$ ) and $\mathrm{N}\left(1.7000 \mathrm{~g} \mathrm{~L}^{-1}\right)$; P1 (P-deficient), with the replacement of $\mathrm{Na}_{2} \mathrm{HPO}_{4}$ and $\mathrm{NH}_{2} \mathrm{PO}_{4}$ by $\mathrm{Na}_{2} \mathrm{SO}_{4}$ and $\mathrm{KCl}$, respectively; $\mathrm{P} 2$, with an intermediate concentration of non-limiting P $\left(0.06 \mathrm{~g} \mathrm{~L}^{-1}\right)$; N1 (N-deficient), with the replacement of $\mathrm{NaNO}_{3}$ by $\mathrm{NaCl}$; and $\mathrm{N} 2$, with an intermediate concentration of non-limiting $\mathrm{N}\left(0.005 \mathrm{~g} \mathrm{~L}^{-1}\right)$.

To conduct the experiment, aliquots of the four strains were placed in five Erlenmeyer flasks, each containing $1000 \mathrm{ml}$ of modified ASM-1 medium. These cultures were maintained for six days under controlled conditions, acclimated to $25^{\circ} \mathrm{C}$, with a 12:12 $\mathrm{h}$ photoperiod and light intensity of 2595 lux. Then, the strains were inoculated into 180 Erlenmeyer flasks of $125 \mathrm{ml}(\mathrm{n}=3)$, each containing $110 \mathrm{ml}$ of a strain with the appropriate medium, totaling 60 Erlenmeyer flasks for each strain. Finally, the cultures were maintained at one of three temperatures $\left(13^{\circ} \mathrm{C}, 25^{\circ} \mathrm{C}\right.$ or $\left.37^{\circ} \mathrm{C}\right)$ for eight days.

Samples were taken on the $1 \mathrm{st}$, 4 th and 8 th days of the experiment for dry weight estimation, extraction of lipids and biomass determination.
Dry cell weight was determined according to Rai et al. (1991). A known volume of algal culture was centrifuged at 5,000 rpm for $5 \mathrm{~min}$, and the harvested biomass was dried at $60^{\circ} \mathrm{C}$ to constant weight.

The extraction of total lipids followed the protocol of Bligh and Dyer (1959), but without added water. Thirty $\mathrm{ml}$ was collected by centrifuging at 5,000 rpm for $5 \mathrm{~min}$, and the harvested biomass was dried at $60^{\circ} \mathrm{C}$ to constant weight (M1). Then, $2 \mathrm{ml}$ chloroform and $4 \mathrm{ml}$ methanol were added and the mixture maintained for $24 \mathrm{~h}$ at $25^{\circ} \mathrm{C}$. The mixture was then agitated in a vortex for $2 \mathrm{~min}$. Two milliliters of chloroform was again added and the mixture agitated vigorously for $1 \mathrm{~min}$. The lower layer was filtered through a $90 \mathrm{~mm}$-diameter filter paper into a pre-weighed glass tube. Evaporation was carried out in a water bath and the residue was further dried at $104^{\circ} \mathrm{C}$ for $30 \mathrm{~min}$. The weight of the vial was again measured (M2). Lipid content was calculated by subtracting M1 from M2, and was expressed as \% dry cell weight (dcw).

Concomitantly with the removal of the samples for lipid extraction, $5 \mathrm{ml}$ of each culture was placed in a vial, labeled and preserved with $1 \%$ Lugol Acetic for the quantification of algal biomass. Quantification followed the method of Utermöhl (1958), and the settling time followed Lund et al. (1958). Biomass $\left(\mathrm{mm}^{3} \mathrm{~L}^{-1}=\mathrm{mg} \mathrm{L}^{-1}\right)$ was estimated by multiplying the values for density by the biovolume of each species (Hillebrand et al. 1999).

A descriptive statistical analysis of data obtained from the lipid extraction and biomass quantification was performed. A factorial ANOVA For Repeated Measures was performed to test the variation in the percentage of lipids with respect to the different temperature and nutrient treatments, and the days during the experiment on which the samples were extracted, by the SPSS 16.0 program. One-way ANOVA and T tests were used to test the significance of the maximum increases of lipid. In cases where the requirements for homogeneity of variances and normality of the data were not 
met, the respective non-parametric tests (KruskalWallis and Mann-Whitney) were used. Data were transformed by arcsine. Simple linear regression analysis was performed to demonstrate the change in the percentage of lipid against the concentration of algal biomass. For the last three analyses, the statistical program Systat 13.0 was used.

\section{RESULTS}

\section{STRAIN LECV-1}

Total biomass in this strain of $M$. contortum was $2931.8 \mathrm{mg} \mathrm{L}^{-1}$. At the end of the experiment, compared to the control medium $\left(657.95 \mathrm{mg} \mathrm{L}^{-1}\right)$, this strain showed the highest biomass when grown in $\mathrm{P} 2$ medium (1068.25 mg L $\mathrm{mg}^{-1}$ ) and the lowest in the N2 medium (298.61 $\left.\mathrm{mg} \mathrm{L}^{-1}\right)$. On the eighth day, the algal biomass was usually highest in the culture maintained at $37^{\circ} \mathrm{C}$.

With respect to the days when the lipids were extracted, the highest values usually occurred on the first day in treatments P1, N1 and N2, at a temperature of $13^{\circ} \mathrm{C}$; however, these values were not significant for the control treatment $(p>$
0.05). At this same temperature, the lipid content increased $16 \%$ in the control medium. At the control temperature $\left(25^{\circ} \mathrm{C}\right), \mathrm{N} 2$ showed the best lipid content $(100 \%)$, on the eighth day, compared to the other treatments. The P1 medium was the only one where the lipid variation was not significant with respect to temperature and to the days on which extractions occurred $(p>0.05)$.

On average, the highest total lipid content (88.18\%) was found when strain LECV-1 was exposed to $37^{\circ} \mathrm{C}$ and maintained in $\mathrm{N} 2$ medium $(\mathrm{t}=-2.967, \mathrm{df}=16, p=0.009)$. The culture media in which nitrate concentrations were modified showed higher lipid contents, except for the value obtained at $13^{\circ} \mathrm{C}$ in the control medium (Fig. 1).

STRAIN LECV-2

Total biomass in this strain of $M$. contortum was $3201.3 \mathrm{mg} \mathrm{L}^{-1}$. At the end of the experiment, compared to the control medium $\left(751.36 \mathrm{mg} \mathrm{L}^{-1}\right)$, this strain showed the highest biomass in $\mathrm{P} 2$ (1460.45 $\mathrm{mg} \mathrm{L}^{-1}$ ) and the lowest in the N1 medium (193.30 $\left.\mathrm{mg} \mathrm{L}^{-1}\right)$. On the eighth day, higher values of algal biomass were usually observed at $25^{\circ} \mathrm{C}$.

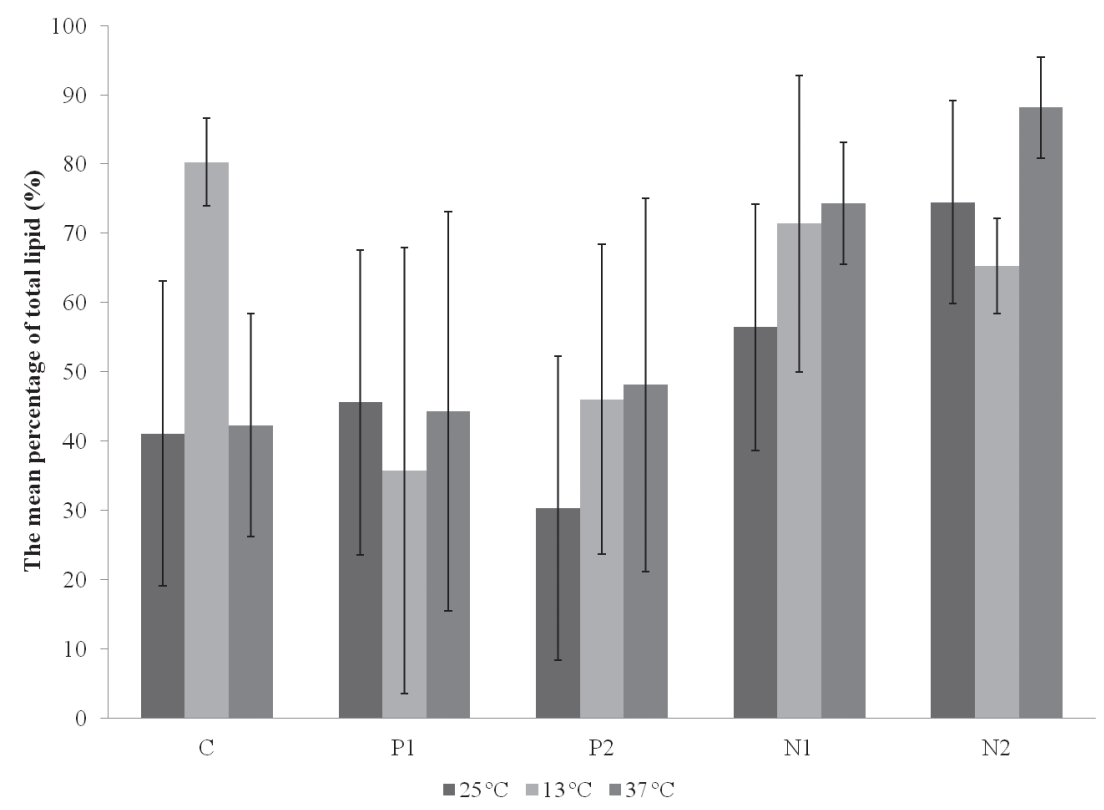

Fig. 1 - Comparison of the overall mean percentage $(n=3)$ of total lipids found in strain LECV-1, with respect to the interaction of factors (temperature and nutrients). 
Overall, for strain LECV-2, the first day of lipid extraction also showed the highest levels of total lipids, when maintained in $\mathrm{P} 1, \mathrm{~N} 1$ and $\mathrm{N} 2$ media, at $13^{\circ} \mathrm{C}$, although this increase was not significant $(p>0.05)$. The lipid content increased $126 \%$ in relation to the control at this same temperature, increasing from $37.5 \%$ to $100 \%$. At the control temperature $\left(25^{\circ} \mathrm{C}\right)$, the means for N2 and N1 showed the highest lipid concentration $(100 \%)$ on the first day and fourth extraction.
However, when maintained in the control medium and $25^{\circ} \mathrm{C}$, this strain showed the best lipid percentage $(92.22 \%)$, on the fourth day. The variation in the lipid content in P1 medium was also not significant with respect to temperature or to the days when extractions occurred $(p<0.05)$. On average, culture media N1 and $\mathrm{N} 2$ showed the highest percentages of total lipids, and the best result $(97.61 \%)$ was obtained at $13^{\circ} \mathrm{C}$ in $\mathrm{N} 2$ medium ( $\mathrm{t}=-3.518, \mathrm{df}=16, p=0.003)$ (Fig. 2).

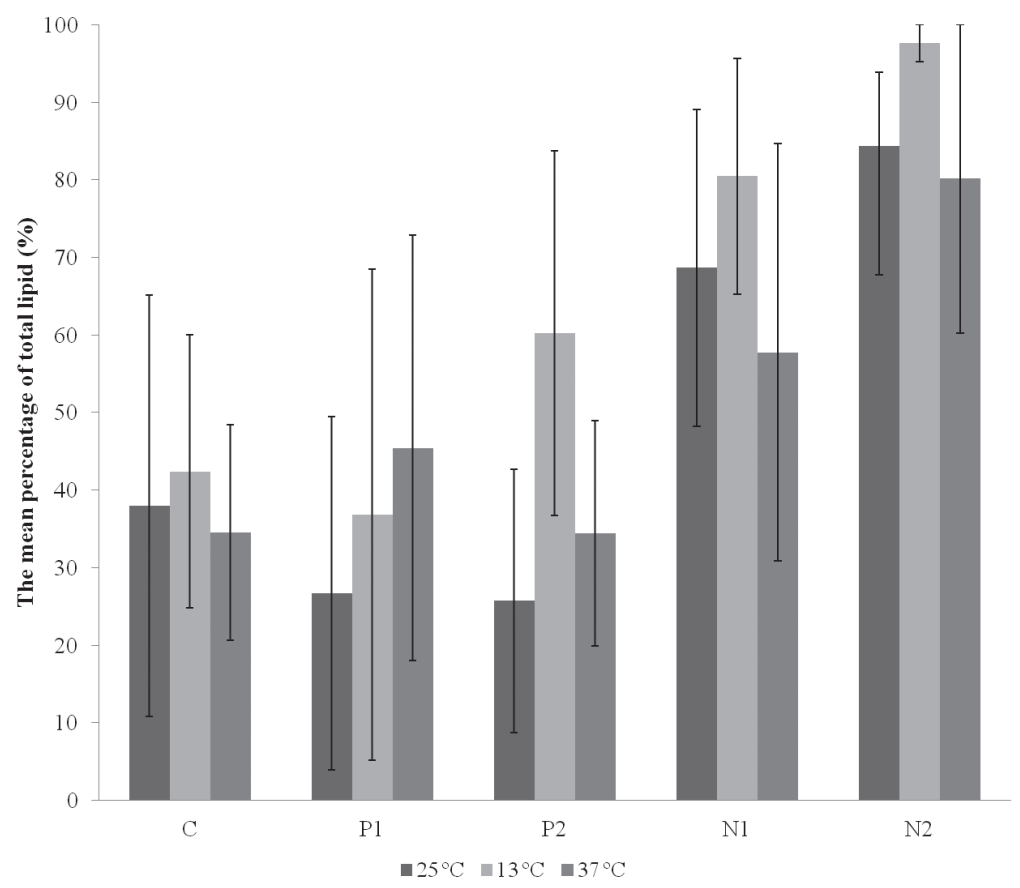

Fig. 2 - Comparison of the overall mean percentage $(n=3)$ of total lipids found in strain LECV-2, with respect to the interaction of factors (temperature and nutrients).

\section{Culture LeCV-3}

The species D. quadricauda and C. vulgaris, present in culture LECV-3, had a total biomass of $3857.1 \mathrm{mg} \mathrm{L}^{-1}$ (3694.4 $\mathrm{mg} \mathrm{L}^{-1}$ and $162.7 \mathrm{mg} \mathrm{L}^{-1}$, respectively). D. quadricauda accounted for $95.78 \%$ of the biomass found for this mixed culture, and C. vulgaris, $4.21 \%$. At the end of the experiment, in the control medium, LECV-3 showed higher biomass $\left(2395.95 \mathrm{mg} \mathrm{L}^{-1}\right)$ in relation to the other treatments. The lowest value was observed when the strain was maintained in $\mathrm{N} 2$ medium $\left(67.89 \mathrm{mg} \mathrm{L}^{-1}\right)$. The highest values of algal biomass were usually observed on the eighth day, at $25^{\circ} \mathrm{C}$.
The highest percentages of total lipids were usually observed on the first day of lipid extraction in $\mathrm{P} 1, \mathrm{P} 2, \mathrm{~N} 1$ and $\mathrm{N} 2$, at $25^{\circ} \mathrm{C}$, although these percentages were not statistically significant compared to the control ( $p>0.05)$. The lipid content increased $102 \%$ (from $44.11 \%$ to $100 \%$ ) in relation to the same temperature control. At $25^{\circ} \mathrm{C}$, better results were obtained in P1, P2 and N2, all with $100 \%$ on the first day of extraction. For the overall average, the highest percentage of lipids was reached at $13^{\circ} \mathrm{C}$ in $\mathrm{N} 2$ medium $(85.66 \%)$ $(\mathrm{U}=19.000, \mathrm{df}=1, p=0.043) . \mathrm{N} 1$ and $\mathrm{N} 2$ showed the highest lipid content (Fig. 3). 


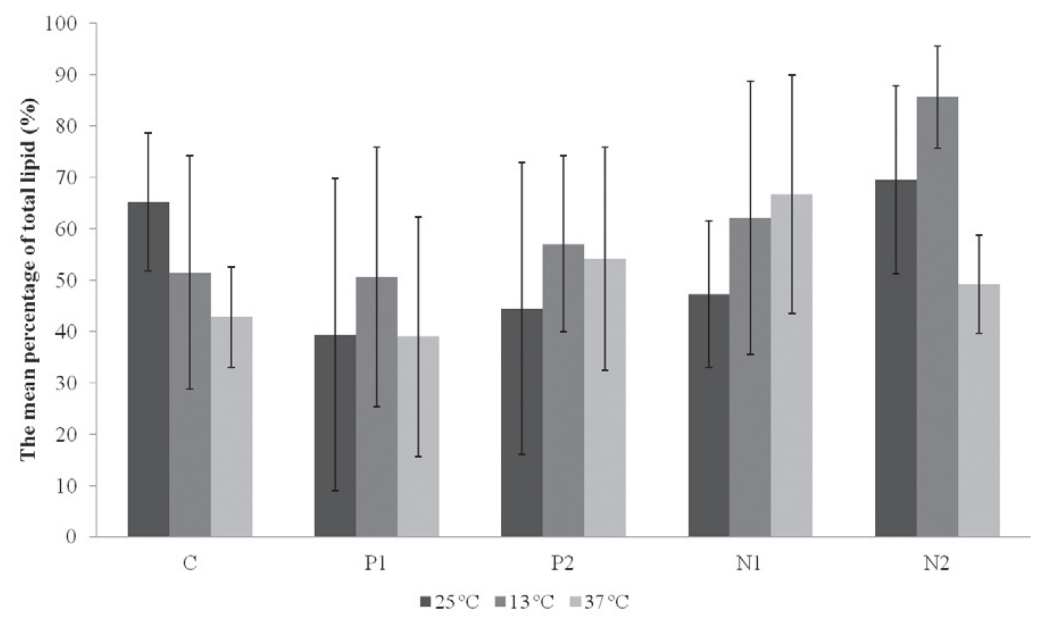

Fig. 3 - Comparison of the overall mean percentage $(n=3)$ of total lipids found in culture LECV-3, with respect to the interaction of factors (temperature and nutrients).

\section{STRAIN LEA-04}

The total biomass of $M$. aeruginosa was $327.3 \mathrm{mg}$ $\mathrm{L}^{-1}$. At the end of the experiment, in relation to the control $\left(61.35 \mathrm{mg} \mathrm{L}^{-1}\right)$, this strain showed the highest biomass when grown in P1 (70.12 $\left.\mathrm{mg} \mathrm{L}^{-1}\right)$ and the lowest in medium P2 (47.43 $\mathrm{mg} \mathrm{L}^{-1}$ ). Higher values of algal biomass were usually observed on the eighth day, at $25^{\circ} \mathrm{C}$.

Strain LEA-04, as well as all other strains, generally showed better total lipid contents on the first day of the lipid extraction, in P1, P2, N1 and $\mathrm{N} 2$, at $13^{\circ} \mathrm{C}$, with a mean increase of $258 \%$ $(\mathrm{H}=10.432, \mathrm{df}=4, p=0.034)$. At the control temperature, the highest levels of lipids were found in the N2 medium, on the fourth day (100\%). In control conditions (temperature and culture medium controls), LEA-04 reached the highest lipid percentage $(79.6 \%)$, also on the fourth day. In the overall average, in $\mathrm{N} 2$ medium at $25^{\circ} \mathrm{C}$ this strain reached the highest percentage of total lipids (90.65\%) (U=20.000, df=1, $p=0.043)$. The media where nitrate concentrations were manipulated showed the highest values of total lipids (Fig. 4).

INTEGRATED ANALYSIS OF LIPID PERCENTAGE

The lipid content did not vary significantly among strains $(p>0.05)$. The lipid percentage varied significantly according to the extraction days $\left(F_{3,120}=79.064, p<0.001\right)$. On the first day of extraction, the strains maintained in culture media P1 and N2 had the best percentages of total lipids, regardless of the temperature at which they were cultured. On the fourth day, the best results were observed in medium $\mathrm{N} 1$ at $37^{\circ} \mathrm{C}$. On the eighth day, N2 showed the best lipid content, regardless of the temperature treatments. Overall, algae in N2 medium showed the highest lipid content $\left(\mathrm{F}_{4,120}=19.662, p\right.$ $<0.001)$, P1 $\left(\mathrm{F}_{4,120}=19.662, p<0.001\right)$, followed by $\mathrm{P} 2\left(\mathrm{~F}_{4,120}=19.662, p<0.001\right)$ and $\mathrm{N} 1\left(\mathrm{~F}_{4,120}=\right.$ $19.662, p<0.001)$. With respect to temperatures, the lipid percentage was statistically different at $13^{\circ} \mathrm{C}$ $\left(\mathrm{F}_{2,120}=6.703, p=0.005\right)$. At $37^{\circ} \mathrm{C}$ the observed difference was not significant $(p>0.05)$. For all strains, the percentage of lipid varied linearly with the increase in algal biomass $(p<0.05)$.

\section{DISCUSSION}

Manipulation of temperature and nutrients influenced the lipid content produced in the four strains. All strains responded similarly to the experiments, generally providing their best lipid percentage on the first day of the experiment, in the N2 culture medium and at the temperature of $13^{\circ} \mathrm{C}$. The highest concentrations of algal biomass were normally obtained on the eighth day, in the P2 medium and 


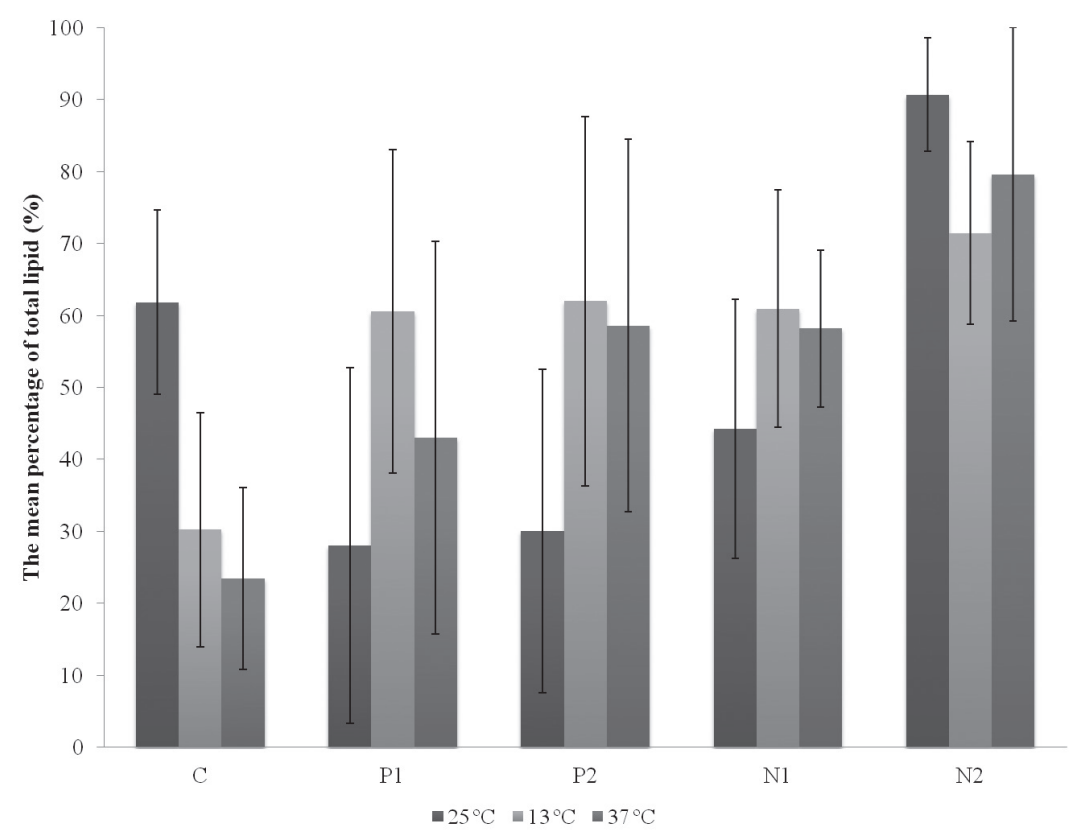

Fig. 4 - Comparison of the overall mean percentage $(n=3)$ of total lipids found in strain LEA-04, with respect to the interaction of factors (temperature and nutrients).

temperature of $25^{\circ} \mathrm{C}$. The percentage of lipid varied according to biomass in all strains, indicating that strategies to increase the biomass can be exploited to increase the lipid content for purposes of oil production.

Microalgae are considered good feedstock for biofuels because of their high potential for lipid production. The lipid percentage in microalgae is normally around $20-50 \%$ of biomass (Brennan and Owende 2010), but may reach $80 \%$ (Sporalore et al. 2006, Chisti 2007). In the present study, high lipid percentages ( $84.44 \%$ and $92.22 \%$ ) were found in strains LECV-1 and LECV-2, on the fourth day of the experiment, higher than values cited by other studies (Tomasini et al. 2008).

The differences observed, especially between the two strains of $M$. contortum (LECV-1 and LECV-2), can be attributed to differences in lipid biosynthesis, which can occur not only between taxonomically different organisms but also between strains of the same species (Aquarone et al. 1983).

Several factors might influence lipid production in laboratory experiments with microalgae.
The duration of culture (culture time) can significantly affect lipid productivity (Mandal and Mallick 2009). With respect to the days when the extraction of lipids was performed, all strains generally had the highest lipid contents on the first day, including the treatments P1 and N1 (LECV-1 and LECV-3), P1, P2, and N2 (LECV-2) and P1, $\mathrm{P} 2$ and N1 (LEA-04) at a temperature of $13^{\circ} \mathrm{C}$. The concentrations of $\mathrm{N}$ and $\mathrm{P}$ in the culture medium might be limiting factors, directly influencing the growth of microalgae and accumulation of lipids. Deficiencies of these nutrients have been found to effectively induce lipid accumulation in microalgae (Watanabe et al. 1983, Feng et al. 2012). However, because the factors that affect oil production are the same that affect growth, when $\mathrm{N}$ and $\mathrm{P}$ are limited, the biomass tends to decline. This would explain why, generally, the highest lipid content was found on the first day of lipid extraction, and the highest algal biomass on the eighth day. This pattern was observed in strains LECV-1 (N1 medium), LECV2 (P1, P2, N1 and N2 media), LECV-3 (P1, P2 and N1 media) and LEA-04 (P1 and P2 media), 
in both phosphate- and nitrate-modified media. For all strains, culture media in which the nitrate concentration was manipulated showed the best lipid contents, particularly with an intermediate concentration of non-limiting nitrate.

In Chlorophyceae and Cyanobacteria, nitrogen stress correlates well with the increase in lipid content (Watanabe et al. 1983, Griffiths and Harrison 2009). This may explain the generally higher amount of lipid in N2 medium, where the nitrate concentration was lower than that of the control medium in which these strains were maintained prior to the experiment. The tendency to increase lipid levels as a result of deficiency in nitrate concentrations has been demonstrated in other studies (Shiflin and Chisholm 1981, Illman et al. 2000, Mandal and Mallick 2009, Feng et al. 2012). Manipulating $N$ and P, Feng et al. (2012) reported that lipid accumulation in Chlorella zofingiensis $(65.1 \%)$ during $\mathrm{N}$ deficiency was greater than that found with P deficiency (44.7\%), suggesting that the $\mathrm{N}$ deficit was more effective in promoting a significant increase in lipid content in this species. Phosphate limitation also appears to stimulate the accumulation of lipids (Rhee 1978).

With respect to temperature, other studies have found that an increase in the mean temperature may also favor lipid concentration (Paoletti et al. 1980). However, in this study, a decrease of 12 degrees $\left(25^{\circ} \mathrm{C}\right.$ to $\left.13^{\circ} \mathrm{C}\right)$ resulted in the largest increases in lipid content, in most of the strains, demonstrating that temperature stress might also favor lipid synthesis.

Few studies have tested the potential of bluegreen algae to produce a sufficient amount of lipids for biofuel purposes. In the present study, strain LEA-04 showed high percentages of lipids, especially in non-limiting nitrate conditions, unlike published reports that Cyanobacteria usually contain low levels of lipids, regardless of culturemedia manipulations (Aquarone et al. 1983). As stated by Reynolds (1984), Cyanobacteria store all their reserves when exposed to stress. This may explain the good lipid values found in this study.

In summary, the results obtained here showed that the changes in the percentage of lipids due to temperature and nutrient manipulation, as well as time were significant $(p<0.05)$, although no significant differences were observed among the lipid contents of the four strains themselves $(p>0.05)$. The strains tested can be considered as potential producers of lipids, provided that the culture medium, the temperature, and the days of lipid extraction are correctly adjusted. This study demonstrated that it is possible to increase the lipid concentration of the green and blue-green algae tested by manipulating important resources such as temperature and concentrations of $\mathrm{P}$ and $\mathrm{N}$, especially imposing nitrogen stress and lowering the temperature, conditions in which the strains showed higher lipid concentrations.

\section{ACKNOWLEDGMENTS}

We thank the Conselho Nacional de Desenvolvimento Científico e Tecnológico (CNPq, process 550280/ 2010-3) of Brazil for financial support. We are grateful to Dr. Janet W. Reid (JWR Associates) for revising the English.

\section{RESUMO}

A produção de biomassa energética através de microalgas é considerada uma alternativa limpa em relação a outras que demandam amplas áreas para cultivo e são geradoras de impactos ambientais. Esta pesquisa avaliou a influência da temperatura e nutrientes no teor de lipídios de culturas de espécies de microalgas de água doce, visando o uso destes lipídios para a produção de biodiesel. Para isso, duas cepas de Monoraphidium contortum, uma cepa contendo as espécies de Chlorella vulgaris e Desmodesmus quadricauda e outra cepa de Microcystis aeruginosa, foram mantidas em laboratório, por seis dias, em cinco meios de cultura ASM-1 modificados (controle com altas concentrações de fosfato e nitrato; sem fosfato; com concentração intermediária não limitante de fosfato; sem nitrato; e o último com 
concentração intermediária não limitante de nitrato). Posteriormente, foram submetidas às temperaturas de $13^{\circ} \mathrm{C}, 25^{\circ} \mathrm{C}$ (controle) e $37^{\circ} \mathrm{C}$, durante oito dias $(\mathrm{n}=3)$. Os lipídios foram extraídos utilizando-se solventes a frio, com a mistura de metanol e clorofórmio. Em média, as maiores produções lipídicas totais foram observadas quando as cepas foram mantidas em $13^{\circ} \mathrm{C} \mathrm{e}$ no meio com concentração intermediária não limitante de nitrato. O percentual lipídico variou em função da concentração de biomassa algal. Este estudo mostrou que manipulações de fatores determinantes podem induzir maior concentração lipídica, otimizando a produção total com vistas à utilização desta matériaprima para o biodiesel.

Palavras-chave: biomassa energética, Monoraphidium, Chlorella, Desmodesmus, Microcystis, acumulação de lipídios.

\section{REFERENCES}

Aguiar DG AND AZEVEdo SMFO. 1992. Produção de toxina por Microcystis aeruginosa em diferentes fases de cultivo e concentrações de nitrogênio. Rio de Janeiro: CETESB, 6 p.

AQUARONE E AND ZANCANARO JÚNIOR O. 1983. Vinagres. In: AQUARONE E, LIMA UA and BORZANI W (Eds), Alimentos e Bebidas Produzidos por Fermentação, São Paulo: Edgard Blucher, São Paulo, Brasil, p. 210-215.

BEHRENS PW AND KYLE DJ. 1996. Microalgae as a source of fatty acids. J Food Lipids 3: 259-272.

BLIGH EG AND DYER WJ. 1959. A rapid method for total lipid extraction and purification. Can J Biochem Physiol 37: 911-917.

Borges L, FAria BM, Odebrecht C AND ABreu PC. 2007. Potencial de absorção de carbono por espécies de microalgas usadas na aqüicultura: primeiros passos para o desenvolvimento de um "Mecanismo de Desenvolvimento Limpo". Atlântica 29: 35-46.

BRENNAN L AND OWENDE P. 2010. Biofuels from microalgae. A review of technologies for production, processing and extractions of biofuels and co-products. Renew Sustain Energy Rev 14: 557-577.

Cheng Y, Lu Y, Gao C And Wu O. 2009. Alga-Based Biodiesel Production and Optimization Using Sugar Cane as the Feedstock. Energ Fuel 23: 4166-4173.

ChIsti Y. 2007. Biodiesel from microalgae. Biotechnol Adv 25: 294-306.

DANTAs EW, Moura AN AND BitTEnCOURT-OliveIra MC. 2011. Cyanobacterial blooms in stratified and destratified eutrophic reservoirs in semi-arid region of Brazil. An Acad Bras Cienc 83: 1327-1338.
FENG P, DENG Z, FAN L AND HU Z. 2012. Lipid accumulation and growth characteristics of Chlorella zofingiensis under different nitrate and phosphate concentrations. J Biosci Bioeng 114: 405-410.

Goldemberg J. 2009. Biomassa e energia. Quím Nova 32: 582-587.

GRIFFITHS MJ AND HARRISON STL. 2009. Lipid productivity as a key characteristic for choosing algal species for biodiesel production. J Appl Phycol 21: 493-507.

HAAG AL. 2007. Algae bloom again. Nature 447: 520-521.

HARWOOD JL AND GUSCHINA IA. 2009. The versatility of algae and their lipid metabolism. Biochimie 91: 679-684.

Hillebrand H, DÜrselen D, Kirschtel D, Pollingher U AND ZOHARY T. 1999. Biovolume calculation for pelagic and benthic microalgae. J Phycol 35: 403-424.

Huang G, Chen F, Wei D, Zhang X And Chen G. 2010. Biodiesel production by microalgal biotechnology. Appl Energy 87: 38-46.

ILlMAN AM, SCRAGG AH AND SHALES SW. 2000. Increase in Chlorella strains calorific values when grown in low nitrogen medium. Enzyme Microb Technol 27: 631-635.

Lund JWG, KIPLING C AND LECREN ED. 1958. The inverted microscope method of estimating algal numbers and the statistical basis of estimations by counting. Hydrobiologia 11: 143-170.

Mandal S AND MaLlick N. 2009. Microalga Scenedesmus obliquus as a potential source for biodiesel production. Appl Microbiol Biotechnol 84: 281-291.

MATA TM, MARTINS AA AND CAETANO NS. 2010. Microalgae for biodiesel production and other applications: A review. Renew Sustain Energy Rev 14: 217-232.

Paoletti C, Vicenzini M AND BocCi F. 1980. Composizione biochimica generale delle biomasse di Spirulina platensis e Spirulina maxima. In: Materassi R (Ed), Prospecttive della Ricerche, Florence: Accademia dei Georgofili, Florence, Italy, p. 111-125.

PLÁ JÁ. 2002. Perspectivas do biodiesel no Brasil. Indic Econ 30: 179-190.

Rai LC, Mallick N, Singh JB AND Kumar HD. 1991. Physiological and biochemical characteristics of a copper tolerant and a wild type strain of Anabaena doliolum under copper stress. J Plant Physiol 138: 68-74.

REYNOLDS CS. 1984. The Ecology of Freshwater Phytoplankton. Cambridge University Press, Cambridge.

RHEE GY. 1978. Effect of N:P atomic ratio and nitrate limitation on algal growth, cell composition and nitrate uptake. Limnol Oceanogr 23: 10-25.

SHIFLIN NS AND CHISHOLM SW. 1981. Phytoplankton lipids: interspecific differences and effects of nitrate, silicate and light dark cycles. J Phycol 17: 374-384.

Smith VH, STURm BSM, Noyelles FJD AND BiLlings SA. 2010. The ecology of algal biodiesel production. Trends in Ecol Evol 25: 301-309.

SPORALORE P, JOANNIS-CASSAN C, DURAN E AND ISAMBERT A. 2006. Commercial applications of microalgae. J Biosci Bioeng 101: 87-96. 
TOMASINI D, AHRENS VM, ZAMBERLAM F AND D'OCA MGM. 2008. Determinação do teor de lipídios de microalgas visando à obtenção de biodiesel. In: Machado AG (Ed), Anais do XVI Encontro de Química da Região Sul. Blumenau: Odirizzi, Blumenau, Brasil, p. 676.

UTERMÖHL H. 1958. Zur Vervolkommnung der quantitativen Phytoplankton-Methodik. Mitt Int Ver Theor Angew Limnol 9: 1-38.
WALKER DA. 2009. Biofuels, facts, fantasy, and feasibility. J Appl Phycol 21: 509-517.

Watanabe T, KitAJima C AND FuJita S. 1983. Nutritional values of live organisms used in Japan for mass propagation of fish: A review. Aquaculture 34: 115-143. 